\title{
Exploration and Practice of Network Virtual Practice Teaching of Ideological and Political Theory Courses in Colleges and Universities
}

\author{
Ji Zhang*, Luqiong Zuo
}

\author{
School of Marxism, Guilin University of Electronic Science and technology, Guilin, Guangxi, China \\ *Corresponding author. Email: lake222@126.com
}

\begin{abstract}
The use of network virtual technology to reform and improve practical teaching of ideological and political courses in colleges and universities is to actively respond to the needs of information technology development, adapt to the needs and characteristics of today's college students, help to overcome the difficulties of traditional practical teaching of ideological and political courses in colleges and universities, improve the effect of practical teaching of ideological and political courses in colleges and universities. In the construction strategy, attention should be paid to the establishment of a complete network virtual practice teaching system, the combination of network virtual practice teaching and theoretical teaching, and the combination of network virtual practice teaching and traditional practice teaching. In specific practice, virtual practice teaching can be carried out on the basis of network teaching platform, virtual practice teaching platform can be developed, process evaluation can be implemented, and network virtual practice teaching guarantee system can be established.
\end{abstract}

Keywords: Ideological and political theory course, virtual network, practical teaching

\section{INTRODUCTION}

Practice teaching is an indispensable part of Ideological and Political Theory Course (hereinafter referred to as "Ideological and political course"). Nowadays, with the rapid development of information technology software and hardware platform represented by artificial intelligence, big data and Internet, virtual reality technology has changed people's life style and learning style more and more profoundly. Therefore, the practice teaching of Ideological and political theory course in Colleges and universities needs to keep pace with the times. The introduction of network virtual technology and innovation of practice teaching mode are needed to improve the pertinence and effectiveness of practice teaching of Ideological and political course in Colleges and universities. It is an inevitable trend and beneficial exploration to reform and improve the practical teaching of Ideological and political courses in Colleges and universities in the new era by using the network virtual technology [1].

\section{POSSIBILITY AND PRACTICAL SIGNIFICANCE}

First, proactively respond to the needs of information technology development.
$\mathrm{VR}$ is adopted to create an immersive learning environment to create an "autonomous learning" environment. The application prospect of virtual practice teaching in ideological and political courses in colleges and universities is worth looking forward to. From the perspective of learning resources, most of the major historical events and important historical figures emerging in China's modern and contemporary history can be expressed in the form of documentaries, films and pictures. The use of network virtual technology for scene reproduction can restore the historical scene to a large extent, so that students have the feeling of immersive, immersive, review the history [2]. It is necessary to strengthen the information construction of practical teaching of ideological and political courses, break through the shackles of traditional practical teaching mode, transcend the limitation of time and space, realize the benign interaction between teachers and students, enhance the attraction of practical teaching of ideological and political courses in colleges and universities, and stimulate the enthusiasm and initiative of students to participate in practical teaching.

Second, to adapt to the needs and characteristics of today's college students will help improve the effect of practical teaching of ideological and political courses in colleges and universities.

The deep integration of virtual practice teaching and ideological and political courses in colleges meets the needs of contemporary ideological and political education for college students. The development of information technology has caused a profound change in the means and 
forms of ideological communication. The relatively single traditional practice teaching of ideological and political courses in colleges and universities can no longer meet the diversified needs of contemporary college students, while virtual practice teaching is a learning method they are willing to accept. The virtual reality technology is introduced into the practice teaching of ideological and political courses, which enriches the practice teaching form and turns the content infusion into three-dimensional interaction. The colorful and immersive virtual practice teaching content can provide students with more intuitive and vivid simulation experience from visual, tactile, auditory and other aspects, which is conducive to enhancing the attraction of practical teaching of ideological and political courses in colleges and universities, encouraging college students to study independently, and training their ability of independent thinking.

\section{BUILD STRATEGY}

By carrying out virtual practice teaching, the deficiency of traditional practice teaching can be made up and the quality of practice teaching of ideological and political courses in colleges and universities can be guaranteed. Create a practical teaching class with diversified forms, rich contents and standardized management, strengthen the integration of virtual practice and traditional practice, and realize the unity of knowledge and practice in practical teaching of ideological and political courses in colleges and universities.

First, the establishment of a complete network virtual practice teaching system.

The smooth implementation of network virtual practice teaching is inseparable from the guarantee of relevant rules and regulations. At the college level, the overall practice teaching plan, work regulations, assessment methods, workload calculation methods and other management documents for ideological and political courses should be formulated, and detailed network virtual practice teaching plans should be formulated to effectively manage each link in the practice teaching process. Through the formulation of relevant documents and plans, the practice teaching objectives of ideological and political courses are clearly defined, the practice teaching management is complete, the practice teaching content system is appropriate, the assessment system is scientific, the guarantee system is effective, and the practice teaching of ideological and political courses is standardized and institutionalized, so as to improve the operability of practice teaching.

Second, the combination of network virtual practice teaching and theoretical teaching.

Ideological and political courses in colleges and universities integrate ideological, political, moral and practical aspects. The unity of theoretical and practical aspects is a major feature of ideological and political courses in colleges and universities. The teaching goal of ideological and political course contains both theoretical and practical aspects, including the mastery of knowledge and theory, as well as the application of relevant theories to analyze and recognize the society, participation in social practice activities, and finally the integration of knowledge and practice and internalization in the mind. Theoretical teaching is the main channel and foundation, practical teaching is indispensable compensation and extension. It is the fundamental requirement of ideological and political courses in universities to make the theory clear and thorough, while students' internalized acceptance of knowledge and clear understanding of theories need to be tested and sublimated through practical activities. The theory and practice of ideological and political courses in colleges and universities complement each other. Theoretical teaching needs to deepen and practice the understanding of the theory learned through practical teaching, while practical teaching also needs to return to the theoretical level to sublimate and verify the theory.

Thirdly, the combination of network virtual practice teaching and traditional practice teaching.

Network virtual practice teaching does not completely replace the traditional practice teaching, but the expansion and further deepening of the latter. The combination of network virtual practice teaching and traditional practice teaching introduces a new world of interaction and benign interaction between network and reality. By making full use of the existing network resources, students can complete the teaching activities related to practice on the network, and visit the memorial hall and museum websites online, such as visiting the main conference site online and the former site of zunyi conference, so as to achieve the effect of combining theory with practice. Abundant network resources provide abundant practical subjects for practical teaching of ideological and political courses in colleges and universities.

\section{MEASURES TO BE TAKEN}

Under the guidance of the strategy, teachers of ideological and political courses develop and constantly improve the teaching plan, make clear the purpose of practical teaching, and complete the practical teaching. Specific measures are as follows:

First of all, based on the network teaching platform, virtual practice teaching is carried out.

Online and offline hybrid teaching has become the trend of Ideological and political teaching reform in Colleges and universities, and practical teaching is no exception. Relying on the network teaching platform used, such as classroom school, rain class, etc., push social hot spots and focus issues on the platform, simulate the process of practice in the form of graphic or video clips, and restore the course of events [3]. Organize the students to fully discuss the relevant issues, guide the students to use the theoretical knowledge they have learned to analyze and discuss the issues, and submit the relevant assignments in the form of questionnaire survey, practice report, etc. for the teacher or teaching assistant to review and give targeted feedback. Based on the online teaching platform, carry out group project tasks. The specific tasks are 
designed by the teacher. The learning group can share materials, discuss interactively and upload and share learning results through the online learning platform. According to the actual situation of students, we should carry out practical activities, in which we should pay attention to students' behavior and thinking.

According to the needs of Ideological and political courses in Colleges and universities, choosing the corresponding network resources can bring students different experiences. For example, organize students to browse the network red resources with practical tasks, so that students can see the red resources with pictures and texts at home. After the students finish the virtual practice teaching, they should organize the students to report and give speeches, even debate and discuss the relevant contents in the classroom. Through this process, the students can further internalize the insights gained in practical teaching and form their own views and understandings. This process not only effectively exercises students' eloquence, but also enables students to internalize what they have learned.

Secondly, the development of virtual practice teaching platform.

The virtual practical teaching resources are developed by using technical personnel. Virtual practice teaching can fully mobilize students' senses and let them have immersive real experience. Through the network transmission technology such as voice, video transmission and data collaboration, and the practice environment related to patterns, students are provided with a virtual practice environment simulating historical scenes. Students feel and experience in the virtual practice teaching of historical situation reproduction. With the help of the Internet and VR technology, our school has developed a network platform for the publicity and education of the red army's long march spirit based on VR technology, thus changing the traditional mode of only viewing pictures and videos for displaying cultural relics online. Realize audio, video, virtual simulation and other interactive display, real tour of the long march pavilion, more quickly and easily to understand the story of the long march and learn the spirit of the long march [4]. At present, the school has completed 13 Long March exhibition halls, including the Red Army Long March Breakthrough Xiangjiang Martyrs Memorial, the Red Army Forced Crossing the Dadu River Memorial, the Marcon Red Army Long March Memorial, and the Huining Red Army Long March Victory Memorial. By visiting the Virtual Long March Pavilion, and then taking the Virtual Long March route, students can experience the hardships of the Long March and the stubborn will and firm belief of the revolutionary ancestors. To provide students with richer content and more diverse practical teaching content. Thirdly, process evaluation is carried out to stimulate students' autonomy in learning.

The principle of combining process evaluation with outcome evaluation, quantitative evaluation with qualitative evaluation is adopted. The assessment content mainly depends on whether students apply the theory to practice teaching activities, whether they deepen their understanding and recognition of the theoretical knowledge they have learned, whether they improve their learning ability, communication ability and writing ability, etc. For the effect of practical teaching, relevant practical reports should be submitted upon request, which can be diversified in forms such as slides, web pages, short videos and electronic magazines to display personalized research results. For students practice teaching evaluation is not only confined to the social practice activity itself, but should also put the students the classroom practice, campus practice activities are included in the inspection scope, establish a multi-dimensional and three-dimensional practice evaluation system, improve the scientific and standardization of practice teaching, the process and result, the combination of ideological content and the combination of technical, not only review the technical content of student finish the homework, more important is to investigate its ideological content, and work content is scientific, innovative, etc., the students practice teaching as an important evaluation index into the course grade. The main body of assessment is diversified, and the combination of self-evaluation, peer evaluation, group evaluation and instructor evaluation can improve students' inquiry-based learning ability.

Finally, the network virtual practice teaching guarantee system is established.

In accordance with the relevant provisions, security education courses in colleges and universities teaching school credits, ensure the funds of the practical teaching, establish a complete system of security, at the same time make clear a regulation education courses in colleges and universities practice teaching target, content, form, school distribution, performance assessment, organization and management, etc, to achieve the standardization and institutionalization of the practice teaching of the college education courses.

\section{SUMMARY}

It is an urgent need to introduce network virtual technology to improve the educational function of practical teaching and improve the practical teaching methods [5] The construction of its three-dimensional network practice teaching system of Ideological and political courses in Colleges and universities can not only expand the time and space of practice teaching, but also enrich the teaching content, enhance the appeal and attraction of teaching, enhance the acquisition of students' learning, and promote the overall development of college students.

\section{ACKNOWLEDGEMENT}

In 2019, innovation Project of Guang Xi Graduate Education, "Research and Practice of a Hybrid Educational Model of Ideological and Political Theory Courses for University Graduates Based on Network Teaching Platforms" (JGY2019083);in 2019, Guangxi key research base of Humanities and Social Sciences 
- the phase of "exploration of virtual practice teaching of outline of modern Chinese history" funded by the government digital communication and Cultural Soft Power Research Center Results (C99SZO00SZ10); Innovation Project of Guet Graduate Education, "Inquiry into the Mode of University Moral Education Home-school Linkage Mode in the Perspective of Informationization" Project Number: "2019YCXS124" Phased Research Results.

\section{REFERENCES}

[1] Hong Chen, Wen Sun. Research on virtual practice teaching of ideological and political theory course in colleges and universities [J]. Ideological and theoretical education guide, 2016.

[2] Bao Chen, Huiqiang liu. Virtual practice teaching: a new exploration of practical teaching reform of ideological and political theory course in colleges and universities with students' independent participation [J]. Ideological and theoretical education guide, 2018(2).

[3] Ji Zhang, Luqiong Zuo. Research on the integration of guilin red cultural resources and ideological and political course teaching in universities under the classroom platform -- a case study of the outline of modern and contemporary history of China [J].

Education modernization, 2019(39).

[4] Jie Sun. Virtual practice teaching of ideological and political course [J]. Ideological and political course teaching, 2017(10).

[5] Jianjun Xu. Theory and method of network ideological and Political Education [M]. People's education press, 2010. 